\title{
A second level of the Saint Petersburg skyline
}

\author{
Andrey Krasnopolsky ${ }^{1}$ and Sergey Bolotin ${ }^{1 *}$ \\ ${ }^{1}$ Saint Petersburg State University of Architecture and Civil Engineering, Department of Drawing, \\ Vtoraya Krasnoarmeyskaya str. 4, Saint Petersburg, 190005, Russia \\ ${ }^{2}$ Saint Petersburg State University of Architecture and Civil Engineering, Department of Basics of the \\ Construction Organization and Management, Vtoraya Krasnoarmeyskaya str. 4, Saint Petersburg, \\ 190005, Russia
}

\begin{abstract}
The article considers the history of the residential development in Saint Petersburg and states corresponding landmark dates. In recent years, changes in the altitude range of the residential development are noted, the influence of this factor on the formation of the city's silhouette is assessed. Reasons for such changes are identified. Attractiveness of high-rise residential complexes for living is assessed. Conclusions are made of tendencies in further housing construction development in terms of its altitude range. It is noted that it is possible to locate multi-storied buildings in the periphery of the city, taking into account specific visual characteristics of the construction site and silhouette of erected buildings; as for central districts, strict regulations regarding the altitude range are needed.
\end{abstract}

\section{Introduction}

Exceptional significance attached to architectural traditions in the life of modern Saint Petersburg distinguishes the city among other metropolitan areas of Russia. The Historic Center of Saint Petersburg and Related Groups of Monuments, included in the World Heritage List in 1990, became the first UNESCO World Heritage Site in Russia (and the USSR). Making this decision, UNESCO took into consideration the fact that "the greatness of the northern capital of Russia, its horizontal silhouette with vertical dominants, ensembles of embankments and squares - all this underlies the "imperial" image of Saint Petersburg, its genius loci" [1].

Specific "horizontal position" of the city's silhouette with a small number of vertical dominants is of special concern of Saint Petersburg citizens; it always affected and affects the multi-storied construction development in Saint Petersburg.

The study encourages to find ways for further regulation of residential development evolution, which would ensure city development, while retaining its appearance and humane environment for people.

\section{Methods}

\footnotetext{
${ }^{1}$ Corresponding author: sbolotin@mail.ru
} 
A comprehensive approach, comprising studies and analysis of the information from literary and Internet sources on housing construction and the legislative framework related to regulations of the building height, serves as the methodological basis of the study. A fullscale survey, photographic fixation and an analysis of city's panoramas were carried out to reveal the influence of multi-storied housing construction. Landmark dates of the city development were identified.

\section{Results}

\subsection{3-1765-1844-1960s. Horizontal position of the Saint Petersburg silhouette}

Founding the northern capital, Peter the Great considered it necessary to demonstrate the greatness and power of the renovated Russia. In 1712, he started the construction of the Peter and Paul Cathedral, and in 1722 - the construction of the Twelve Colleges building. These two buildings determined both the grand scale of the founded city and compositional features of its silhouette. The 400-meter horizontal line of the main government building rose above the trailing and swampy Vasilyevsky Island. The line continued on the Petrograd side with the elongated body of the basilica of the Peter and Paul Cathedral with the bell tower spire ascending to 112 meters over the wide Neva River. Silhouettes of two gigantic structures, having no match over hundreds of miles around, contrasted with 1-2-story wooden and claywalled structures, huts and dugouts in the forest, in which builders lived.

Even in our time, these two buildings can be considered impressive constructions; they honorably present the image of the "new Russia" to the world. In order to assess their perception at the beginning of the $17^{\text {th }}$ century, it should be noted that major gigantic construction projects of Peter the Great were implemented practically from scratch.

Urban-planning development of the capital city remained the prerogative of Russian sovereigns - heirs of Peter the Great. They personally managed the development, looked through projects of all erected buildings, established decision-making committees for the control over the execution of monarchic decisions and development of design proposals. Activities of private entrepreneurs were regulated with the help of administrative measures.

Let us mark out landmark dates of the city development.

1765 - Catherine the Great introduced rules meant to give more greatness to Saint Petersburg:

- it was prescribed to locate buildings along building lines without gaps (to ensure their adjoining) and align them by height on the front facade of blocks: "All houses to be located at the same street should be built as one solid facade with the doorsteps not coming out to the street and the same height along the building line".

-it was proposed to raise the development level, and buildings on front embankments were supposed to have the facade height of 10 sazhens (about $21.3 \mathrm{~m}$ ), so that "the buildings along the Neva river in the least would correspond to the stone bank" [2].

Funds for the capital construction flowed in Petersburg from across Russia, nevertheless, the implementation of all these arrangements took a long time: only in the 1810-1830s, during the large-scale reconstruction of the city center under Alexander I, the height of facades on main streets reached 3-4 floors.

1844 - Nicholas I issued the decree "On restriction of high-rise construction in Saint Petersburg and limiting additional structures in existing buildings" [3].

The prohibition was caused by the appearance of 5-story houses in the city. This order is usually regarded as a concern for maintaining the "horizontal position" of the Petersburg silhouette. However, it should be taken into account that the authorities decided to limit the 
representative external appearance of the capital development for the first time in 140 years. The emperor's resolute reaction reminded of the subordination and limited ambitions of individuals: none of developers could erect buildings higher than the eaves of the imperial residence - the Winter Palace $(23.47 \mathrm{~m})$. Only bell towers and cupolas of churches ("only the God is above the tsar") could serve as exceptions. The sovereign Russian emperor followed the way which was paved by European monarchs centuries before. For example, Louis XIV, who was also a strong supporter of the principle of absolute monarchy, allocated plots for the construction in Versailles under the condition to construct buildings not higher than 18.5 meters, that is, the level of the entrance to the palace [4].

In the middle of the $19^{\text {th }}$ century, the panorama of the main city space of Saint Petersburg was finally formed.

The year 1844 should be particularly noted, as it established the reached height of the development skyline in Saint Petersburg. A bit later it was cut by two new high-rise dominants. In 1868, Saint Isaac's Cathedral was consecrated, which for a long time had been surrounded by staging; its height was $101.5 \mathrm{~m}$. A massive colonnade and a gleaming gold cupola rose above the standard development. The reconstruction of the spire of the Peter and Paul Cathedral, carried out in 1857-1858, which brought the total height (including the cross and angel figure) to 122.5 meters, can be considered as a response to the challenge of the erected giant. At that time, the horizontal line of the Saint Petersburg silhouette stabilized (Figure 1). Parameters of determining structures of the historical center of the city have not changed significantly to our days.

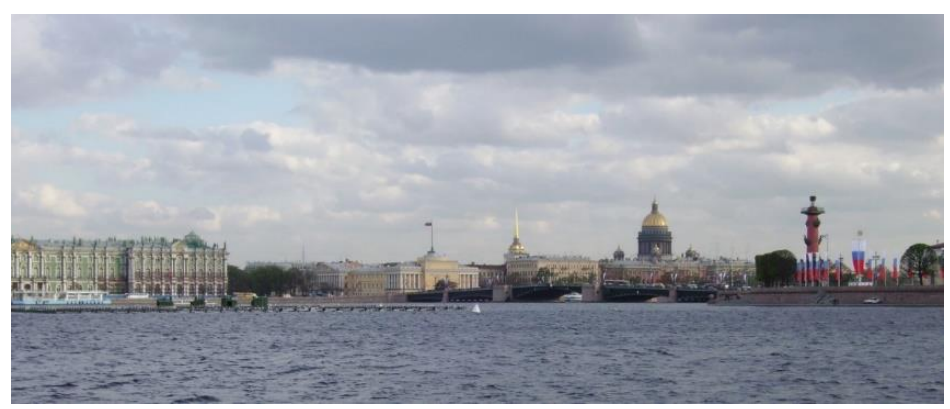

Fig. 1. Modern panorama of the Neva banks: the city development stretched along the horizontal line not exceeding the height of the Winter Palace eaves $(23.47 \mathrm{~m})$, the second highest dominant of the city is the Saint Isaac's Cathedral which rose up to the height of $101.5 \mathrm{~m}$ (photo by L. Lavrov)

In 1900s, prerequisites for adjusting the historical landscape appeared: amendments were introduced to the building code, canceling the height regulation with regard to the ridge of the eaves. Attics appeared in Petersburg immediately (Regulations SP 54.13330.2011 "Multicompartment residential buildings" defines this structural part of the building as follows: "A floor in the attic space, the facade of which is completely or partially formed by the surface (surfaces) of an inclined, kinked or curved roof" [5]). However, in the period before 1917, consequences of the radical administrative decision had no time to manifest on a large scale, and the city retained the obvious "horizontal position" of the development.

In the Soviet period, the city ceased to be the capital of the country. It was destined for the ordinary fate of a regional center, and no ambitions (in the architectural sphere as well) were permitted to manifest in provinces. The subordination was also maintained in terms of the height of buildings. In the 1930s-1950s, the silhouette of the historical center of Leningrad lost quite a lot of verticals - bell towers and cupolas of churches. It was assumed that a system of new dominants would appear instead. However, resources were sufficient only for technical objects which were functionally necessary. Then, water towers of the Meat Processing Plant and the Red Nailery plant (according to the sketch of Ya. G. Chernikhov) 
appeared. A tower of the Kirov District Council was built, and high-rise elements of the Industrial Cooperation House of Culture on Kirovsky Prospect and the Kirov Culture Palace on Vasilyevsky Island were significantly reduced in comparison with their project designs (Figure 2).

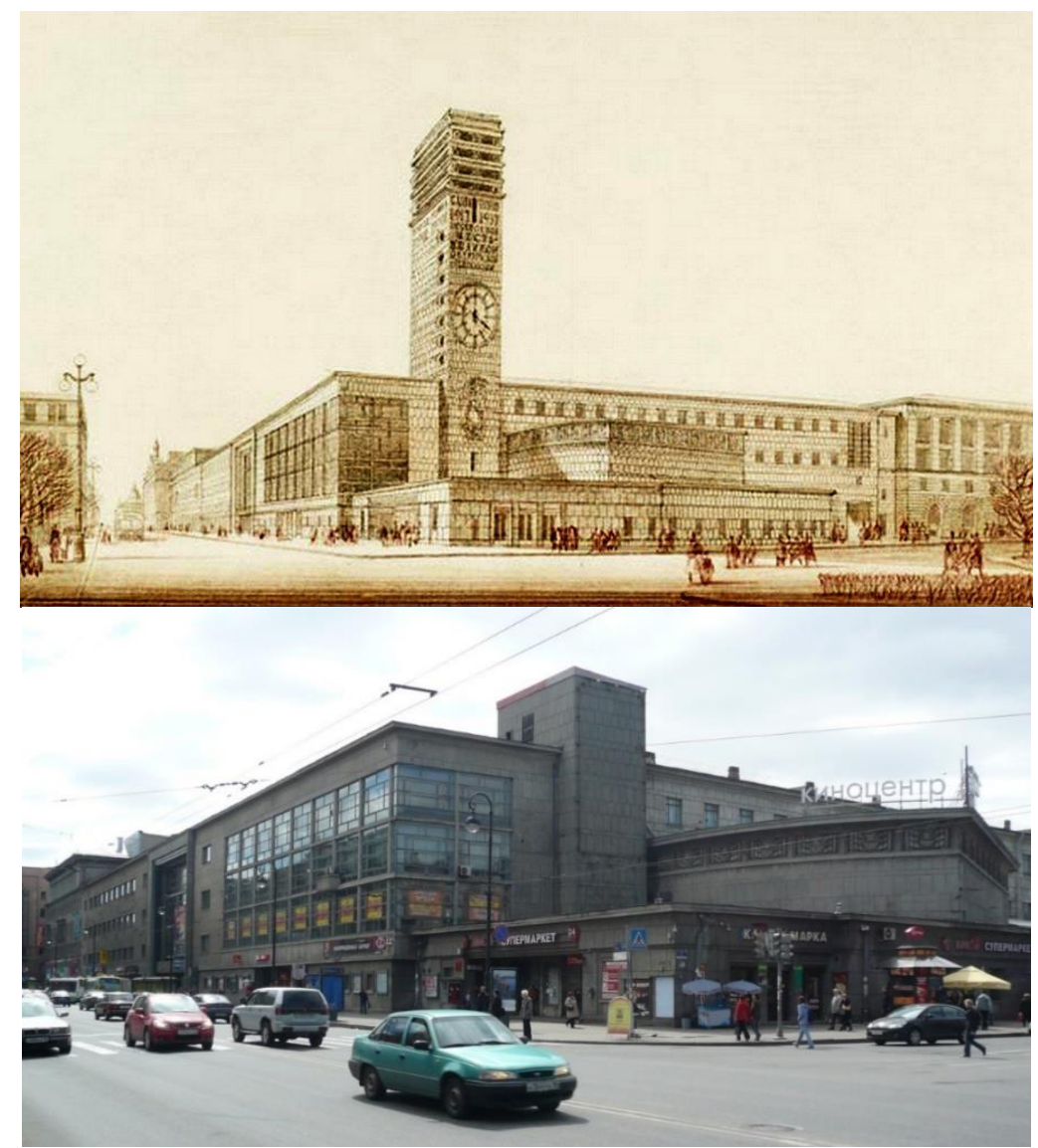

Fig. 2. Building of the former Industrial Cooperation House of Culture. Design drawing by architect Ye. A. Levinson and its full-scale implementation

In the late 1930s, the USSR joined the race of high-rise structures. In Moscow, the construction of a gigantic building of the Palace of the Soviets started; it was supposed to reach the height of $420 \mathrm{~m}$ and surpass the 381-meter American skyscraper - the Empire State Building [6]. In Leningrad, a project of the local House of the Soviets, the overall height of which corresponded to the basement level of the Moscow high-rise structure, can be considered as a response to that.

In the post-war period in Moscow, which should become a "model communist city", seven "Stalin's skyscrapers" were built of up to 200 meters high. In the capital of the Soviet Ukraine, the initiative was supported with a 73 -meter house on the main street $(85 \mathrm{~m}$ high with the spire) [7]. A lot of projects were developed based on this theme in Leningrad, but only a building on Moskovsky Prospect near the Victory Park was erected (Figure 3). 


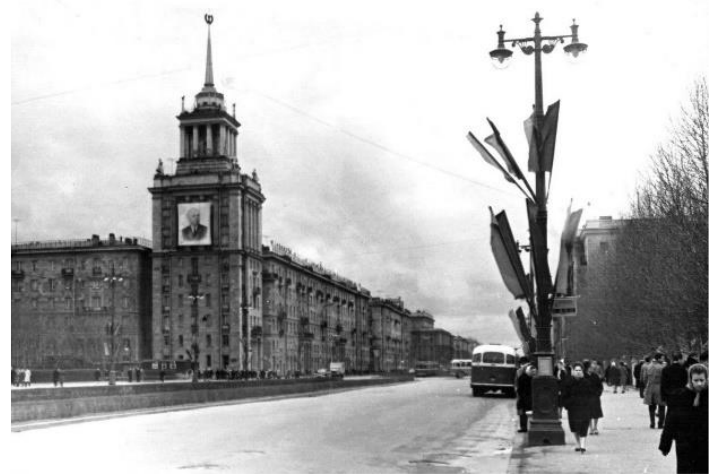

Fig. 3. Multi-storied tower-house on Moskovsky Prospect. Leningrad. Photo of 1962

During post-war restoration in the zone of the historical center, the principle of leveling the height of front facades "under the single eaves" was defining, as it was established in 1765: the missing floors were built up in the destroyed buildings, and tumbledown attic structures were replaced by capital structures in 50 cases [8].

In the 1960s, with the beginning of the Khrushchev's reforms, standard 5-story buildings got widespread, as they were considered then to be the most cost-efficient type of housing. Huge areas in periphery districts were built up with micro-districts with standard large-panel 5 -story buildings. Shortly after that, related problems associated with the city transport and engineering infrastructure appeared. In the 1970s, the development of 9-12-story and, partially, 16-story houses started centrally (Figure 4).

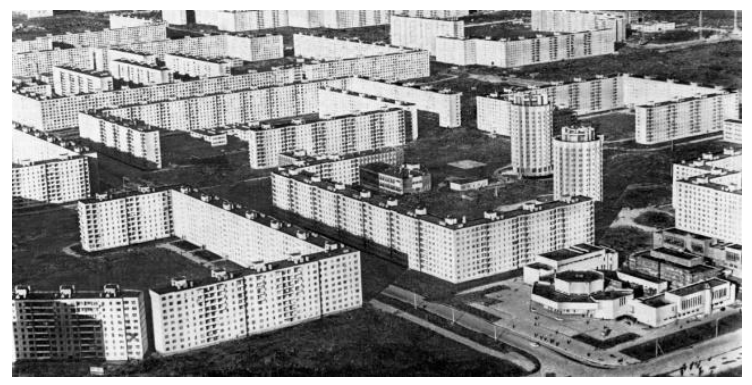

Fig. 4. Development in the Leningrad periphery, typical for the 1980-1990s

In a short time, "high-rise" buildings (with more than 5 floors) occupied monopoly positions in the structure of housing construction in Saint Petersburg, and by 2009 they accounted for more than $2 / 3$ of the total housing stock [9]. Enormous dimensions of erected multi-story buildings in the periphery attracted attention, as they did not correspond to the development, traditional for the city center. The living area in 551 new 16-story residential buildings, built in "bedroom districts" exceeded the living area in 33,399 1-4-story buildings, which formed the basis of the housing stock of the historical part of Saint Petersburg [9].

\subsection{Preserving the "skyline". 1970-2010}

Introduction of multi-story buildings in the city silhouette triggered a negative public reaction in the late 1970s. 22-story residential buildings which were erected in the peripheral district at the Victory Square were perceived then as the monumental complex at the entrance to the city. However, appearance of such buildings in the North-West of Vasilyevsky Island attracted attention of specialists immediately. Architect N. T. Vinokurova took into account 
their location along the embankment of the Smolenka River, in the section line of Nevsky Prospect and pointed out that, due to that, high-rise buildings would be viewed from the center of the city and, moreover, they would create a background for the spire of the Admiralty [10]. Her work can be considered the first study of the new multi-story development influence on the silhouette of the city. A speech of academician D. S. Likhachev, who intensely criticized the appearance of the lapidary silhouette of a high-rise hotel near cupolas of the Trinity Cathedral in the western part of the Fontanka River (Figure 5) and called the 18-story building "violating the skyline typical for Leningrad", can be considered as the beginning of emotional manifestations of public opinion [11].

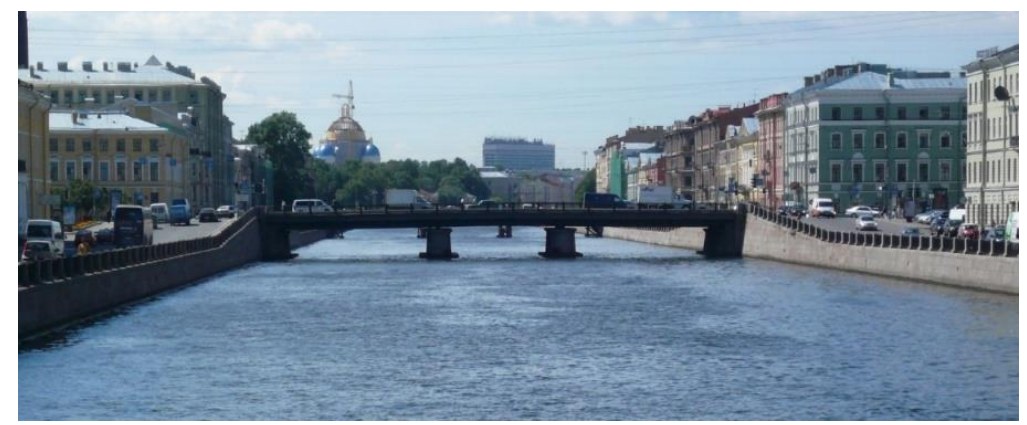

Fig. 5. 18-story building of the hotel in the perspective of the Fontanka River

In our time, the development has turned towards the direction set by financial and economic conditions. The construction industry has undergone tremendous changes over the past 50 years. The most dynamic processes began when the country switched to the market economy. Mass privatization of apartments in the state housing stock started. The land became a commodity. Technical infrastructure enterprises turned into corporations. An official real estate market emerged; housing prices began to grow.

Large profitable projects started to be implemented. The key role is played by expanded construction enterprises and wealthy investors supported by leading banks. In the 2000s, they supported the development of modern technologies for multi-story construction, and areas for 17-25-story buildings and buildings with more stories were allocated in the peripheral districts next to 9-16-story buildings (Figure 6).

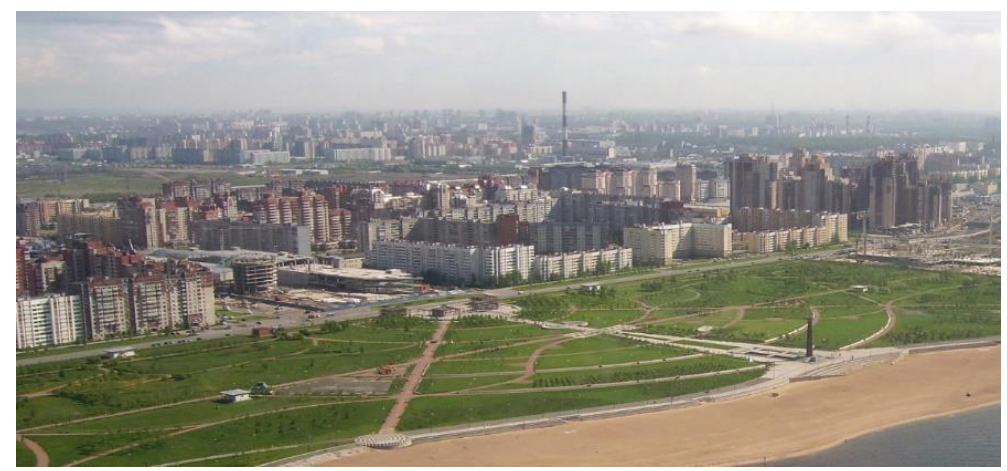

Fig. 6. Development on the northern bank of the Gulf of Finland. 22-25-story blocks constructed at present days are located near 9-12-story buildings erected in the 1990s

The strategy for the location of high-rise and multi-story buildings has changed. In the Soviet times in Leningrad, there were less than ten residential buildings with the height of 
more than 20 floors, and the location for each of them was determined by arrangement and urban-planning considerations. In the modern period, commercial interests became determinative. 20-25-story buildings became a characteristic element of the urban landscape in the peripheral district. Even the highest residential buildings (higher than $100 \mathrm{~m}$ ) appeared in areas, where their construction was based on cost estimates of construction corporations.

The acute struggle with high-rise development has become one of the dynamic and popular trends of the public activity in Saint Petersburg. The struggle between developers and civil activists has been carried out for several decades with varying success. In the early 2000 s, a scandal burst out with regard to the erection of the Mont Blanc multifunctional complex in the area of the historical center on the Vyborgskaya embankment of the Neva River. The construction of a 74.5-meter building was accompanied by the persistent criticism on the part of historic preservation activists. Commercial interest, desire to get more luxury apartments with beautiful views of the historical center panorama played the main role. When the construction object was topped out, it became obvious that the new building was one of the most serious recent urban-planning mistakes of Petersburg. In May 2006, the Urban Council disapproved the Mont Blanc building construction project and stated that the erected building distorted the historical and architectural panoramas of Neva banks. An attempt to introduce some adjustments without decreasing the building altitude was made, but, as the photo shows (Figure 7), it failed.

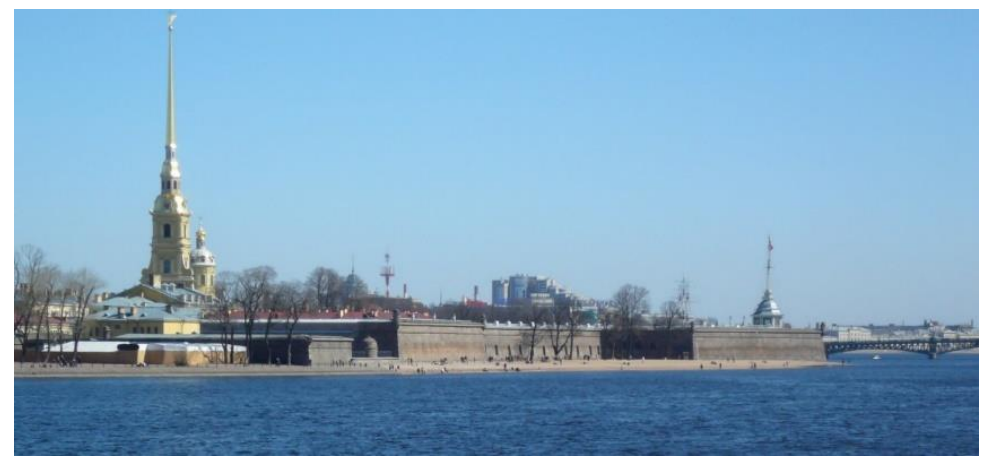

Fig. 7. High-rise volume of the Mont Blanc residential complex in the landscape of the Petrograd side

These days, the building on the bank of the Neva River is an object of the most acute critics. Complaints are also caused by the fact that "the protected panorama of Saint Petersburg was hopelessly crushed by an awkward, tactless, infinitely inappropriate massiveness of this structure" and that the developer used the remarkable potential of the panorama exclusively for commercial purposes (a unique place, where a public observation platform could appear, passed to a private luxury apartment) [12]. Information on general financial results of the sale of the dwelling with panoramic views is not reported, but the cost of 2-room apartments available in this building is 24,500,000 RUB, and the cost of 4-room apartments is 42,900,000 RUB [13].

At the present time, it is difficult to find a site in the city where construction with the same economic effect is possible; changes in laws also prevent such construction.

It is known that apartments with views in the Premier Palace residential complex, surrounding landscapes of which cannot comparable to the unique Mont Blanc situation, are more expensive than standard apartments by 20-30\%. "High-rise housing is targeted, first of all, at residents with incomes much higher than average. As a rule, apartments on upper floors are more expensive than similar ones on lower floors", experts assert [14, 15].

Nowadays, commercial considerations stimulate the increase of building height and number of multi-story residential buildings, but there are no more sites available in the city 
center for this type of construction. At the end of the $20^{\text {th }}$ century, new buildings located in blocks of the historical center posed a risk to the UNESCO protected landscape. The course of events related to the intention to build a skyscraper of 396 meters high near the baroque Smolny Cathedral, which was intended as a dominant of the Okhta Center business complex, found international resonance. It was planned to put it into operation in 2012, but the sharp reaction of citizens and architects caused intense discussion. Active counteraction led to the project failure [16].

At present, multi-story and high-rise buildings are developed in peripheral districts. The issue becomes especially acute due to the ambitious urban-planning program for the development of the "grey belt" of former industrial territories surrounding the city center in a dense semicircle. These are potential construction sites of great attractiveness for investors, as they could be used in residential construction, mainly high-rise. They are located beyond the zone where the horizontal position of the development silhouette is protected by UNESCO. Here, regulations for high-rise construction are less stringent, allowing for the construction of buildings with beautiful panoramic views of the city center. Recently, the spontaneous development of separate sites started here, resulting in that fragments of lapidary high-rise buildings situated in the "grey belt" began to take shape in the center of Saint Petersburg near cupolas of churches and spires of bell-towers (Figure 8). If the process speeds up, then individual unfortunate obstructions can turn into a continuous multi-story wall around the historical urban nucleus.

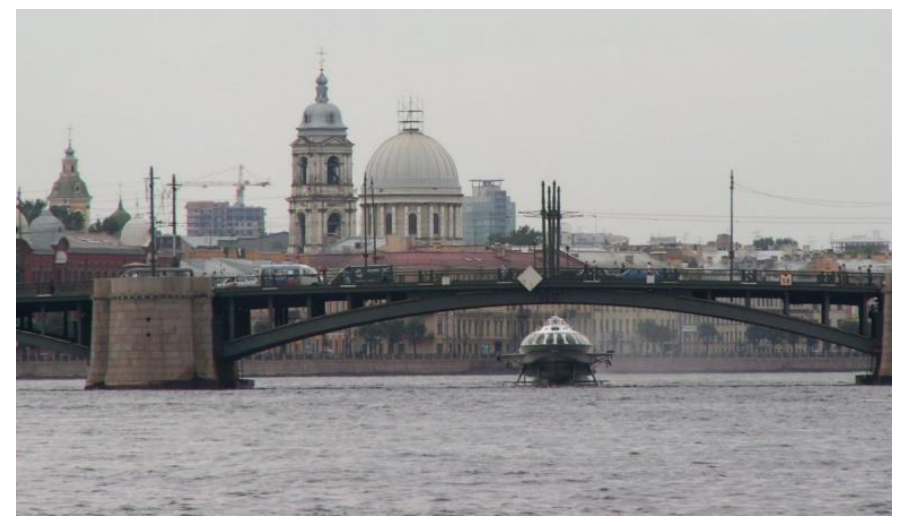

Fig. 8. High-rise buildings erected near the Smolenka river show up unexpectedly in the image of the Saint Petersburg center by Birzhevoy Bridge (Exchange Bridge) (photo by L. Lavrov)

In this regard, "standard" high-rise buildings (from 75 to 100 meters), representing a very common typological group (there were 353 such buildings as of January 15, 2015) are of particular concern. The tendency of forming a characteristic volumetric and spatial solution of such buildings causes apprehension. Building plots are very expensive, and developers counting upon a particular profit, resort to increase the number of floors. Investment calculations stimulate the output in the form of the maximum number of "apartments with views". Peripheral blocks, consisting of 10 houses of 25 floors, are already the reality [17]. Under these conditions, complexes of 25-30-story buildings, having the silhouette in the rectangular form or in the form of a dense group of towers, appear, but that does not correspond to basic compositional characteristics of the traditional Petersburg landscape. Moreover, in this case, it is possible to refer to changes in artistic and aesthetic preferences. In the early $20^{\text {th }}$ century, A. N. Benois emphasized that "the rush toward the West existed from the very foundation of Petersburg" [18]. The tendency established in our years indicates "the rush toward the East" (Figure 9). Drawbacks inherent in such residential complexes are recognized by Saint Petersburg builders: "Exceeding 15-20 thousand square meters per 
hectare, we get residential complexes, which are called "Shanghai". They differ by excessive crowding, lack of greenery and problems with parking lots" [19].

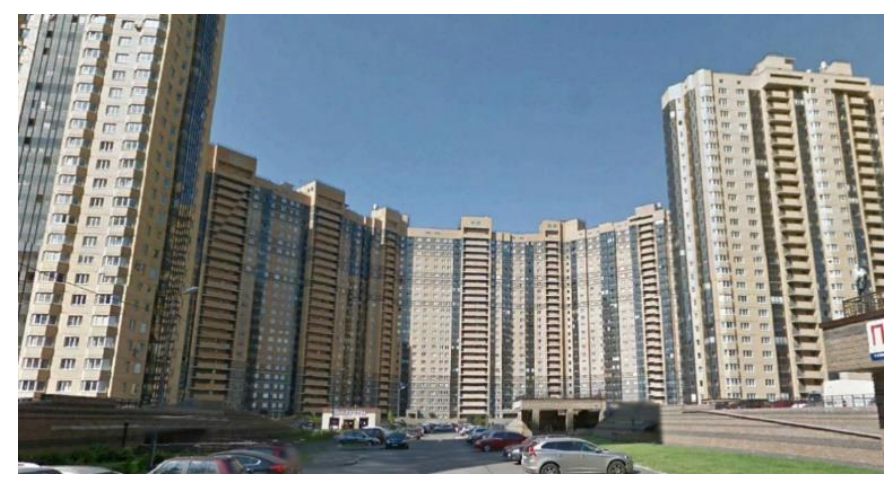

Fig. 9. Parnas, a new residential district in Saint Petersburg

The very limited number of residential buildings having the height of more than 100 meters can be considered as a specific feature of Saint Petersburg. Their main commercial advantage is luxury apartments with a panoramic view of the historic center of the city. The unique horizontal position of the Saint Petersburg landscape reveals many architectural dominants from the "bird's eye view". If sights of the city center can be viewed from windows of the apartment at least from afar, such apartment would cost much more. These buildings are located far enough from the city nucleus. A building providing the desired panoramic view will be viewed from the city center, posing a threat to the purity of the "Petersburg skyline". Such projects are given closer attention by both the city service for the protection of historical monuments and historic preservation activists.

It can be assumed that such choice of building parameters can be explained by ambitions of the developer and potential residents. At present, there are 8 residential buildings with the height of more than 100 meters in the city: Prince Alexander Nevsky (126 m), Bogatyrsky 2 (108 m), London Park (105 m), House at the Komendantskaya Square (105 m), Dominanta (104.5 m), Poem by Three Lakes (100 m), Twin Peaks (100 m) and Raduga (100 m). Seven of them exceed this threshold by only 5-10 meters - to such an extent that to fix the exceeded limit.

As volumes of the construction of multi-story and high-rise buildings increased, investors began to change their attitude to such structures. Problems associated with the increase in number of floors became noticeable. The demand for expensive apartments was declining. Developers report that it is quite difficult to sell apartments above the $17^{\text {th }}$ floor, and highrise residential development with 30 floors and higher (i.e. above 100 meters) is economically unprofitable [20]. In these circumstances, the city administration and leading developers began to exercise restraint and caution in opinions regarding conditions of high-rise construction in the city. Solutions restraining high-rise construction are taken at federal and regional levels. In 2006, Regional Construction Norms "Residential and Public High-rise Buildings. Saint Petersburg" entered into force in Saint Petersburg [21].

These norms cover designing of residential and public buildings with the height of up to $150 \mathrm{~m}$ (residential buildings with the height of more than $75 \mathrm{~m}$, public buildings with the height of more than $50 \mathrm{~m}$ ) and touch upon issues of monitoring, automation and installation of elevators, communication systems, structural as well as architectural and planning solutions, fire-fighting measures, water supply and sewerage systems, foundations and basements.

Later, administrative decisions were taken to restrain the construction of multi-story buildings. For example, in 2011, Federal Government Decree No. 207 “'On requirements for 
the issue of certificates of admission to work on dangerous, technically challenging and unique capital construction facilities to self-regulating organizations" was issued. In 2013, the State Duma of Russia supported changes in the Urban Development Code which prohibited so-called "high-altitude deviations".

\subsection{Attraction of apartments on upper floors is in question}

With the advent of the real estate market, the cost of land plots intended for development became one of determinative factors in setting of characteristics of the created residential environment. Not much territories, where it was possible to conduct housing construction, were left in the city area, and they were located in peripheral zones of Saint Petersburg. High cost of land makes developers, counting upon a particular profit, to push for high density of development: firstly, to increase the number of floors in erected buildings, and, secondly, to place them as close to each other as possible. Vast peripheral territories, where development includes only high-rise buildings, has formed in Saint Petersburg. More and more blocks, consisting of 25-26-story houses, appear on the outskirts of the city [17].

According to the statistical data [9], buildings with the height of 12 floors and more amount to more than $20 \%$ of the city housing stock. At the present time, apparently, these data raise particular concerns, as more and more doubts as to the feasibility of high-rise buildings occur. Besides issues of fire safety, elevators, structure of external walls and certain household inconveniences, great attention is drawn to changes in financial conditions. Deteriorating economic indicators are of great concern. For two decades, financial attractiveness of high-rise buildings in Saint Petersburg was based on the potential of landscapes in the historical center and the view from upper floors. The silhouette of the historical center became the commodity which was sold at a good price. Apartments with views were always in demand, windows with "panoramic" views provided additional fine income. Today, only developers of residential areas in the west of Vasilyevsky Island can reckon on this potential. High-rise peripheral blocks have nothing to offer to wealthy lovers of beautiful panoramas. Landscapes of the historical center cannot be viewed from here; apartments are often located window to window with the neighboring house under construction [22]. There are no enthusiasts for upper floors here. Buyers of low-cost housing do not consider it necessary to pay extra money for panoramic views, as "views from the highest floors on the outskirts of the city are, as a rule, not as attractive as in the center, and there are a lot of concerns - an elevator can go out of order, the wind is stronger at the top" [22]. In particular, the construction of upper floors entails significant technical changes and affects the final cost of the production.

It is obvious that demand conditions make a developer pay attention to prospects of the construction of small apartments in the periphery of the city or in districts adjacent to the Leningrad Region.

\subsection{Low-rise development, with the height of about $30 \mathrm{~m}$}

In April 2014, the city authorities paid attention to prospects of low-rise construction. It was decided to allocate sites in peripheral territories of Saint Petersburg only for low-rise blocks and provide those with infrastructure, probably, using budget funds [17].

The construction industry could not but react to administration intentions, but it was not ready to switch from the cumbersome, but well-developed production mechanism to the development of a new type of buildings, i.e. low-rise residential buildings.

Large holdings agree that they are not ready to take into account advantages of low-rise buildings, which allow for the use of more cost-efficient materials and technologies. It is stated that low-rise buildings should not exceed nine floors (conditionally, up to 30 meters 
high). It would be reasonable to use territories in the Leningrad Region for development, if there are roads and utilities supplied to the site. Monopolists consider the cost of 90,000 RUB per 1 square meter acceptable [23]. This means that the cost of suburban housing should increase by about $20 \%$ (at the present time, the average level is kept, depending on the location and class: 50,000-80,000 RUB per square meter) [24].

Discussions on this issue are still ongoing. Developers persistently refuse to consider 34-story houses as the main object of the prospective construction and focus on prospects of buildings with the "average" number of floors. Most common opinions are the following:

- residential complexes with the medium and small number of floors are more in demand among buyers than high-rise buildings;

- 5-7-story houses are attractive for potential customers who do not want to live in "warrens", but the financial effectiveness of such projects is lower than of high-rise development. A possible solution is to use 6-7-story houses with individual 25-story dominants for the development of residential complexes, such as in the Novoorlovsky residential complex;

- at the present time, mid-rise development is considered an alternative to high-rise buildings [17];

- consumer qualities of a building do not depend on the number of floors. It is difficult for a developer to ensure the economic profitability of the project in mid-rise blocks with the density of 5,000-7,000 square meters per hectare. The optimal density of development in large residential complexes is 10,000 square meters of housing per hectare. About a half from about one million square meters which are built on the outskirts of the Leningrad Region will be of mid-rise development [25].

Attempts to change the terminology instead of renewal of technologies are made:

- 10 years ago, buildings of up to 5 floors were called low-rise, now it is possible to call 9 -stroey buildings low-rise [17];

- taking into account that there are already a lot of houses of 25-26 floors, it is possible to refer buildings of up to 14 floors to low-rise development;

- housing of up to 12 floors is now called "low-rise" housing [17].

At the present time, Saint Petersburg specialists refer buildings of 9 or more floors, which in the 1960s constituted a group of "high-rise buildings", to the category of "low" or "lowrise" buildings, and 9-story houses are called products of low-rise construction.

It is obvious that the planned adjustments of the typology of cost-effective dwelling in Saint Petersburg do not affect principal positions and will not affect quality parameters. The proposed changes are based on the manipulation with terms. Such unproductive approach can be explained by strong inertia of the design, construction and investment complex occupying monopoly positions.

The organizational and economic system of large holdings, covering the entire cycle of the housing production (from upstream operations to architectural and urban-planning designing), is formed with a view to the in-line construction of large multi-story buildings. Low-rise complexes will appear in the suburbs of Saint Petersburg and the Leningrad Region, but their height will vary around the level of 30 meters. Saint Petersburg low-rise buildings will become "the highest low-rise buildings in the world". Developers operating in the economy-class segment prefer to keep their process flows focused on specific features of high-rise buildings without changes, and allow only half-measures: "We used to build houses with the height of up to 27 floors. From now on, we'll build houses of 14-17 floors" [26].

\section{Discussion}

Retaining the image of the historical center of the city is one of the most serious problems associated with high-rise construction in Saint Petersburg. Even upon strict adherence to 
high-altitude regulations for central areas, high-rise buildings appearing on the border with central districts or in the so-called "grey belt" can cause irrecoverable damage to the city silhouette. Attractiveness of high-rise construction for consumers is also doubtful. Its main advantage in Saint Petersburg is the availability of apartments with panoramic views.

At present, tendencies to change the typology of housing occur; concepts relating to the number of floors in buildings are shifted. Buildings, which thirty years ago were referred to high-rise development, are now considered to be low-rise.

It is necessary to ensure strict regulation of further high-rise development in Saint Petersburg, especially on the border with historical regions.

\section{Conclusions}

1. The very limited number of residential buildings having the height of more than 100 meters can be considered as a specific feature of Saint Petersburg. Their main commercial advantage is luxury apartments with a panoramic view of the historic center of the city.

2. Volumes of construction and locations of high-rise buildings in Saint Petersburg are determined by the task of retaining the historical silhouette, therefore, the location of multistory buildings is permissible in the periphery of the city, with account for specific visual characteristics of the building site and the silhouette of erected buildings.

3. High-rise buildings with the coarse rectangular silhouette, the height of which is at the limit permitted by construction regulations, inflict the greatest damage to the silhouette of Saint Petersburg. Their use should be limited in both the former industrial "grey belt" and alluvial territories in the west of Vasilyevsky Island.

4. The discussion on the feasibility of high-rise construction in Saint Petersburg is ongoing, meanwhile "the caravan moves on" and it is reported that about 30 designs of residential buildings with the height of more than 25 floors are currently under implementation in the city.

\section{References}

1. URL:

http://kgiop.gov.spb.ru/media/uploads/userfiles/2015/08/24/\%D0\%94\%D0\%B5\%D0\%BA\%D0 \%BB\%D0\%B0\%D1\%80 \% D0\% B0\% D1\% 86\% D0\% B8\% D1\% 8F_\% D0\% 92\% D0\% A3\% D0\% A6.pdf (accessed date: July 30, 2016).

2. A. V. Bunin, T. F. Savarenskaya History of urban-planning art (Moscow, Stroyizdat, 1979)

3. URL: http://www.nlr.ru/e-res/lawr/search.php?part=483\&regim=3 (accessed date: 05.10. 2017)

4. URL: http://masterok.livejournal.com/296641.html (accessed date: 07.07.2017)

5. Regulations SP 54.13330.2011 "Multicompartment residential buildings", Moscow, 2011.

6. URL:

https://www.wikipedia.org/wiki/\%D0\%94\%D0\%B2\%D0\%BE\%D1\%80\%D0\%B5\%D1\%86_\% D0\%A1\%D0\%BE\%D0 \% B2\% D0\% B5\% D1\% 82\% D0\% BE\% D0\% B2 (10.11.2017)

7. V. N. Stepanov Architecture of the Soviet Ukraine. (Moscow, 1987).

8. History of the Saint Petersburg housing stock development. URL: http://nikonovpn.spb.ru/?p=1059 (accessed date: 25.11 .2017 )

9. URL: http://grinkod.spb.ru/spb_house_fond.html. (accessed date: 25.11.2017)

10. N. T. Vinokurova, B. I. Pokidova, V. P. Fedorov, Silhouette: studies and preservation of the visual perception of the city. Tri Iskusstva, 1, 4-5 (1997)

11. D. S. Likhachev Skyline of the city on the Neva. Our heritage, 1, 8-13 (1989)

12. URL: http://spb.gdeetotdom.ru/articles/1872955-2012-09-10-zhk-monblan-oshibka-kotoruyune-ispravit/ (accessed date: May 5, 2017). 
13. URL:

http://lifedeluxe.ru/catalog/elite/view/monblanhttp://lifedeluxe.ru/catalog/elite/view/monblan (accessed date: June 16, 2017).

14. URL: http://kommersant.ru/doc/2223512 (accessed date: September 27, 2017).

15. URL: http://rway.ru/publication/publication71-2180.aspx (accessed date: September 7, 2017).

16. URL: https://en.wikipedia.org/wiki/Okhta_Center (accessed date: November 6, 2017).

17. URL: http://gorod.spb.ru/articles/2117 (accessed date: September 27, 2017).

18. A. N. Benois Picturesque Petersburg. World of Art, 7 (1) (1902)

19. URL:

http://www.rosned.ru/mnenie_optimalnaya_plotnost_zhiloj_zastrojki_10 tys kv_m zhilya_na gektar// (accessed date: October 11, 2017).

20. URL: http://ppt.ru/news/106118 (accessed date: April 14, 2017)

21. Residential and public high-rise buildings. TSN 31-332-2006 (Regional Construction Norms). Saint Petersburg, Government of Saint Petersburg.

22. URL: https://www.kommersant.ru/doc/2830395 (accessed date: May 25, 2017).

23. URL: http://news.nb.dp.ru/a/2016/05/25/Podvodnie_kamni_malojetazhn (accessed date: May 27, 2017)

24. URL:

http://rucountry.ru/note/maloetagnoi_stroitelstvo_v_sankt_peterburge_107987.html\#ad (accessed date: June 23, 2017).

25. URL: http://www.fontanka.ru/2016/07/06/068/ (accessed date: September 9, 2017).

26. URL: http://www.gazeta.bn.ru/articles/2017/02/09/236998.html (accessed date: September 25, 2017). 